of the trains to run equally well in either direction. The practically universal adoption of the multiple unit system for suburban traffic, where several coaches throughout the train are provided with motors, proves that the flexibility this gives to the make-up of the train is of great value in practice. It is usual to divide the trains into units, each unit consisting of one motor coach and several trailer coaches. In the new express service from London to Brighton, the trains are made up of six or twelve coaches, two or four of which are motor coaches, each being equipped with four 225 horse power motors. Over a new portion of an American railway where the stops are 1.55 miles apart, the average speed including stops is 31 miles per hour; on another portion of the line where the stops are 2.9 miles apart the average speed is 40 miles per hour. The increase over the speed of steam trains in Great Britain is about 50 per cent. This speed could be easily increased; it is merely a question of cost. Mr. Lydall considers that on main lines it would be found advisable to work not less than one third of the passenger train mileage by multiple unit stock. By electrification the average speed of passenger trains in Britain could be raised by 25 per cent. The combination of greater comfort, higher speed, and more frequent service would attract many more passengers, and the latter two would also enable the railways to recover much of their goods traffic which at present goes by road transport.

\section{Motor Car Lights on the Road}

WHEN motor cars pass each other at night time, there is often a blinding glare in the drivers' eyes. We learn from Science Service that, in the United States, the Bureau of Standards has been conducting an extended research on head-lights to discover how glare can be avoided. Dr. Dickinson of the Bureau of Standards concludes that the most important difficulty in obtaining safe head-lighting is the great disparity in brightness between beams from different lamps. One head-light beam is frequently ten times as intense as another. The driver with the dim lights experiences an almost complete lack of visibility when his car plunges into the bright light of the approaching car. Dr. Dickinson suggests that if the lights were kept so that no head-lamp was more than two or three times brighter than another, most of the glare problem would be solved. Most drivers rely on what they can see of the curb rather than what they see of the oncoming car. Hence the light is increased for a hundred feet in front of the car and the beam is widespread horizontally and slightly depressed. Few motorists realise that it is more dangerous to pass a car that is standing still than one that is running fairly fast. A driver in judging whether the road is clear relies on what he has seen during the past few seconds by the light of the oncoming car. But the road immediately at the back of a car at rest is not illuminated in this way and so danger may lurk there unseen. Exposed lights along the roads sometimes increase the risks of night driving. They often make objects almost invisible which could easily be seen by the head-lights alone.

\section{Early Days of the Turbine}

IN his inaugural address as chairman of the NorthEastern Centre of the Institution of Electrical Engineers, Mr. C. Turnbull gave interesting reminiscences of some of the initial difficulties Sir Charles Parsons met in perfecting the steam turbine. His experiments with early forms of the turbine were in entirely new and unexplored regions of engineering. Everything had to be found out. Steel discs were run under stresses that no one could calculate and no one knew whether they were safe or not. The early high-speed turbines ran at 4,800 revolutions a minute. But thanks to the wonderful care always taken at Parsons's works, accidents were very rare. When driving dynamos at high speeds, the armature reaction caused great difficulty. Several solutions were adopted for turbo-alternators. In one way the brushes were moved automatically with the load by steam pressure and the variation of the strength of the field was counteracted by special windings. A further difficulty was that owing to the springing of the shaft, the connexions between the armature and the commutator used to give trouble. This was overcome by the use of flexible connectors, a device first proposed by Parsons. It has proved of the greatest value. Details are given of the famous Turbinia and the heartbreaking experiences with the destroyers Viper and Cobra. Mr. Turnbull tells how Parsons refused to give up and how his perseverance ultimately led to success. Another great invention that came from Parsons's works was the invention of means for balancing high-speed machinery. The early days of the steam turbine were hard days and the labour expended seemed to lead to nothing. At one time it was doubtful if the steam turbine would ever become practical. The story of Parsons's life should prove very encouraging to young and old inventors.

\section{The New Helm or Steering Orders}

Througr the work of the International Safety at Sea and Load Line Convention, and the passing of the Merchant Shipping Act, 1932, and in accordance with the subsequent instructions of the Board of Trade, on January 1 the 'direct' system of helm orders came into use on all British vessels. For centuries the order to "Starboard the helm" or "Port the helm" has caused the ship's head to go in the opposite direction, the practice having come down through the centuries when tillers were in use. Under the new regulations the order "Starboard" will be given, when it is intended that the wheel, the rudder blade and the head of the ship should go to starboard, and the order "Port" will be given when it is intended that the wheel, the rudder blade and the ship's head should go to port. Though it is expected that little difficulty will be experienced in changing over from the 'indirect' system to the 'direct' systern, for a time the orders will be given in the words "Wheel to Starboard" and "Wheel to Port", thus enabling the helmsman to adapt himself gradually to the new system. Like most innovations of the kind, the change in 